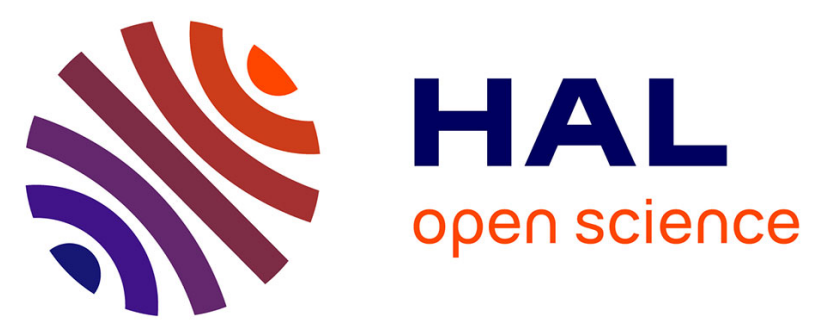

\title{
Temporal Shifts in Plant Diversity Effects on Carbon and Nitrogen Dynamics During Litter Decomposition in a Mediterranean Shrubland Exposed to Reduced Precipitation
}

Mathieu Santonja, Alexandru Milcu, Nathalie Fromin, Anaïs Rancon, Ammar

Shihan, Catherine Fernandez, Virginie Baldy, Stephan Hättenschwiler

\section{To cite this version:}

Mathieu Santonja, Alexandru Milcu, Nathalie Fromin, Anaïs Rancon, Ammar Shihan, et al.. Temporal Shifts in Plant Diversity Effects on Carbon and Nitrogen Dynamics During Litter Decomposition in a Mediterranean Shrubland Exposed to Reduced Precipitation. Ecosystems, 2019, 22 (5), pp.939-954. 10.1007/s10021-018-0315-4 . hal-01928001

\section{HAL Id: hal-01928001 \\ https://hal-amu.archives-ouvertes.fr/hal-01928001}

Submitted on 20 Nov 2018

HAL is a multi-disciplinary open access archive for the deposit and dissemination of scientific research documents, whether they are published or not. The documents may come from teaching and research institutions in France or abroad, or from public or private research centers.
L'archive ouverte pluridisciplinaire HAL, est destinée au dépôt et à la diffusion de documents scientifiques de niveau recherche, publiés ou non, émanant des établissements d'enseignement et de recherche français ou étrangers, des laboratoires publics ou privés. 
1 TiTLE: Temporal shifts in plant diversity effects on carbon and nitrogen dynamics during litter

2 decomposition in a Mediterranean shrubland exposed to reduced precipitation

3

4 RUNNING HEAD: Litter diversity effects on $\mathrm{C}$ and $\mathrm{N}$ dynamics

6 Authors: Mathieu Santonja ${ }^{1,2 *}$, Alexandru $\mathrm{Milcu}^{3,4}$, Nathalie Fromin ${ }^{3 \dagger}$, Anaïs Rancon ${ }^{1}$, 7 Ammar Shihan ${ }^{3}$, Catherine Fernandez ${ }^{1}$, Virginie Baldy ${ }^{1}$, Stephan Hättenschwiler $^{3}$

\section{ADDRESSES}

10 1. Aix Marseille Univ, Univ Avignon, CNRS, IRD, IMBE, Marseille, France.

11 2. Univ Rennes, CNRS, ECOBIO UMR 6553, 35000 Rennes, France.

12 3. Centre d'Ecologie Fonctionnelle et Evolutive (CEFE), CNRS, Univ Montpellier, Univ Paul 13 Valéry Montpellier 3, EPHE, IRD, Montpellier, France.

14 4. Ecotron Européen de Montpellier, Unité Propre de Service 3248, Centre National de la 15 Recherche Scientifique (CNRS), Campus Baillarguet, 34980 Montferrier-sur-Lez, France.

$16 \uparrow$ current address: PROMES/CNRS, 7 rue du Four Solaire, 66120 Odeillo, France.

17

*CORRESPONDING AUTHOR

19 Email: mathieu.santonja@gmail.com;

20 ORCID: 0000-0002-6322-6352 


\section{AbStract}

Climate and plant diversity are major determinants of carbon $(\mathrm{C})$ and nitrogen $(\mathrm{N})$ dynamics in decomposing plant litter. However, the direction and extent to which these dynamics are affected by combined changes in climate and biodiversity is not well understood. We used a field experiment in a Mediterranean shrubland ranging from one to four shrub species with partial rain exclusion $(-12 \%)$ to test how lower precipitation interacts with shrub species diversity to influence $\mathrm{C}$ and $\mathrm{N}$ release during decomposition. We also distinguished between first-year (0-12 months) and second-year decomposition (12-24 months) to test the hypothesis of stronger diversity effects at the beginning of the decomposition process. Litter C and $\mathrm{N}$ release increased with litter species richness during the first year, but not during the second year of decomposition. However, these richness effects were weak and less consistent than litter composition effects, which persisted over time and became even stronger for $\mathrm{C}$ release after two years of decomposition. Partial rain exclusion reduced $\mathrm{N}$ release by $17 \%$ only during the first year and had no effect on $\mathrm{C}$ release in either year. Community weighted mean (CWM) traits and functional dissimilarity (FD) of litter traits contributed both to explain litter species composition effects. These litter trait effects were not altered by partial rain exclusion, but were more important after two years than after one year of decomposition. Our findings suggest increasing trait legacy effects with ongoing decomposition. More generally, our data showed that changes in the diversity of dominant shrub species had stronger effects on $\mathrm{C}$ and $\mathrm{N}$ release during litter decomposition than a moderate reduction in precipitation.

\section{KEY WORDS}

Biodiversity-ecosystem functioning; community weighted means; decomposition stage; functional trait dissimilarity; garrigue; litter functional traits; rainfall exclusion 


\section{HighLights}

$48 \quad-\quad$ Changing plant diversity affected litter decomposition more than reduced rainfall

- Less rainfall did not change $\mathrm{C}$ but reduced $\mathrm{N}$ release after one year of decomposition 


\section{INTRODUCTION}

Ongoing climate change and biodiversity loss are projected to considerably alter the structure and function of Earth's ecosystems (Bellard and others 2012). The degree of these alterations and their consequences for human societies are difficult to predict and may strongly differ depending on the specific geographical area (Pearce-Higgins and others 2015). With its position at the transition from the European temperate zone to the dry subtropical zone in Africa and the Middle East, the Mediterranean basin may be particularly sensitive to climate change, especially to shifts in the precipitation regime (Giorgi 2006; Mariotti and others 2008). Indeed, regional climate models predict a decrease in the amount of precipitation, and an increase in both temperature and the periods without precipitation in the Mediterranean region in the near future (Giorgi and Lionello 2008; Dubrovsky and others 2014; Polade and others 2014). The geographical position between two major climate zones, among other factors such as geological complexity and evolutionary history, also contributes to the exceptionally rich Mediterranean biological diversity (Cowling and others 1996; Thompson 2005), making the Mediterranean basin one of the ten biodiversity hotspots worldwide (Médail and Quézel 1999; Myers and others 2000).

Climate and the diversity of plant communities (i.e. the richness and the composition of species) are two major drivers of ecosystem processes such as productivity and decomposition. Yet, the combined effects and relative importance of changes in climatic conditions and biodiversity are poorly understood and have only rarely been addressed experimentally (Vogel and others 2013). Decomposition of dead organic matter governs the rate at which the carbon and nutrients immobilized in dead tissues are made available for microbial and plant growth (Swift and others 1979). Because microbial activity depends strongly on temperature and moisture conditions, climatic variables are long known as key drivers of decomposition (Swift and others 1979; Berg and others 1993; Coûteaux and others 1995). Recent studies showed that 
variation in microclimate at local scales is a more important factor explaining differences in decomposition rates than the traditionally considered continental-scale variation in macroclimate (Bradford and others 2016; Joly and others 2017). Moreover, site-specific differences in litter quality among co-occurring plant species account overall for more variation in litter decomposition than differences in environmental factors across broad latitudinal gradients (Cornwell and others 2008). Therefore, relatively small changes in microclimatic conditions and shifts in plant species composition may strongly affect $\mathrm{C}$ and nutrient dynamics during decomposition at small spatial scales.

Changing plant species composition can modify litter quality control over decomposition in two ways. First, according to the "mass-ratio hypothesis" (Grime 1998; Garnier and others 2004) litter trait control over decomposition shifts along with the change in the average litter quality, expressed as community-weighted mean (CWM) traits (Quested and others 2007; Mokany and others 2008; Laughlin 2011). Second, according to the "niche complementarity hypothesis" (Petchey and Gaston 2006; Diaz and others 2007) a change in the functional diversity (FD) of trait-values affects the degree at which complementary resource use occurs in the decomposer community (Wardle and others 1997; Vos and others 2013; Barantal and others 2014; Handa and others 2014). These two mechanisms can operate simultaneously in affecting litter decomposition following a shift in plant (litter) composition (Garcia-Palacios and others 2017). Moreover, the relative importance of CWM-trait and FDtrait control may strongly differ for $\mathrm{C}$ and $\mathrm{N}$ release patterns from decomposing litter mixtures (Garcia-Palacios and others 2017), suggesting that C and N dynamics are distinctly affected by changes in plant community composition. However, $\mathrm{C}$ and $\mathrm{N}$ dynamics are rarely addressed together in studies evaluating biodiversity effects on decomposition, especially in Mediterranean ecosystems (but see Handa and others 2014; Garcia-Palacios and others 2017), 
101 and it remains unknown how $\mathrm{C}$ and $\mathrm{N}$ dynamics respond to a concomitant change in plant

102 diversity and precipitation.

103 Because it is generally assumed that initial differences in litter quality among different

104 plant species converge during litter decomposition (e.g. Moore and others 2005; Preston and

105 others 2009), trait mediated litter diversity control on decomposition should be maximal during

106 the initial stage of decomposition, but is expected to decrease in importance during later

107 decomposition stages. However, this hypothesis has not been specifically tested so far. A recent

108 experimental test of how the relative importance of microclimate, litter quality and decomposer

109 community control over decomposition changes over time showed that abiotic control factors

110 increase in their relative importance in later compared to earlier decomposition stages (Garcia-

111 Palacios and others 2016). Based on these results, we expect that the relative importance of the

112 effects of trait-mediated litter diversity and decreased precipitation would shift with ongoing

113 decomposition towards less litter diversity but more microclimate control. The disentangling of

114 the relative importance of a combined change in precipitation and plant community diversity

115 on $\mathrm{C}$ and $\mathrm{N}$ dynamics during different stages of decomposition would improve our

116 understanding of the consequences of ongoing climate and biodiversity change on

117 biogeochemical cycling.

118 In a large field experiment, we established 92 plots of all possible combinations of four

119 dominant woody species, half of them with partial rain exclusion, to test how simultaneous

120 changes in plant diversity and precipitation affect decomposition and other ecosystem processes

121 in a Mediterranean shrubland in Southern France. Here we report the data from a 2-year

122 decomposition experiment that was set up to evaluate how $\mathrm{C}$ and $\mathrm{N}$ dynamics are affected by

123 changing plant diversity and precipitation during different decomposition stages. Two previous

124 studies using the same decomposition experiment investigated the effects of plant diversity and

125 precipitation changes on the abundance and diversity of microbial communities in the litter 
126

127

128

130

131

132

133

134

135

136

137

138

139

140

141

142

143

144

145

146

147

148

149

150

after one year of decomposition (Santonja and others 2017a), and on functional diversity of soil microorganisms after one and two years of decomposition (Shihan and others 2017). Here we addressed two entirely different hypotheses using new data. We hypothesized that H1: decreasing plant species richness will have a negative effect on $\mathrm{C}$ and $\mathrm{N}$ release after one year rather than after two years of decomposition, and $\mathrm{H} 2$ : experimental reduction of precipitation will have a negative effect on $\mathrm{C}$ and $\mathrm{N}$ release after two years rather than after one year of decomposition.

\section{MATERIALS AND METHODS}

\section{Study site}

The study was carried out in the Massif de l'Etoile located at the northern end of the Marseille city in southern France $\left(43^{\circ} 22^{\prime} \mathrm{N}, 5^{\circ} 25^{\prime} \mathrm{E}\right)$. The study site is at $275 \mathrm{~m}$ a.s.l. with a mean annual precipitation of $552 \mathrm{~mm}$ and a mean annual temperature of $14.6{ }^{\circ} \mathrm{C}$ (see Santonja and others (2017a) for further details). The soil is a shallow and stony rendzina (66 \% of stones in the top $50 \mathrm{~cm}$ ) on limestone, with a mean depth of $<20 \mathrm{~cm}$, mean $\mathrm{pH}$ of 7.9, mean $\mathrm{C}: \mathrm{N}$ ratio of 18:1 and mean CEC of $36.8 \mathrm{cmol} . \mathrm{kg}^{-1}$ (see Shihan and others (2017) for further details). The vegetation is a woody shrub-dominated "garrigue", with shrub heights ranging between 0.2 and $1.4 \mathrm{~m}$ and a total cover from $25 \%$ to $95 \%$ (Montès and others 2008). Four woody shrub species dominate the community and account for $73 \%$ of total vegetation cover: Quercus coccifera $\mathrm{L}$. (Quercus, with an average cover across all plots of 36\%), Cistus albidus L. (Cistus, 18\%), Ulex parviflorus Pourr. (Ulex, 10\%), and Rosmarinus officinalis L. (Rosmarinus, 9\%) (see Rodriguez-Ramirez and others (2017) for further details).

\section{Experimental setup}


152 briefly we selected plots of different combinations of the four dominant woody shrub species.

153 Those included all 15 possible combinations of single-, two-, three- and four-species mixtures

154 with a replication of six plots per species combination (except for the four-species mixture that 155 was replicated eight times), yielding a total of 92 plots. Half of the plots of each species 156 combination were randomly assigned to a control treatment, and the other half to a partial rain 157 exclusion treatment. The plots were equipped with a $4 \mathrm{~m} \times 4 \mathrm{~m}$ solid aluminum frame, held 2 $158 \mathrm{~m}$ above the ground by aluminum posts at the outer border of the $16 \mathrm{~m}^{2}$ plot area and fixed to 159 the ground with reinforcing bars in October 2011. We mounted stainless steel gutters on top of 160 the aluminum frame. Contrary to the partial rain exclusion plots, the gutters in the control plots 161 were mounted upside down, which means they did not intercept rainfall but affected other 162 microclimatic variables in the same way (e.g. light interception, wind patterns). The rainwater 163 was channeled away from the plots via a supplementary PVC gutter and a pipe fixed at the 164 border of the frame. The density of the gutters was chosen to target an average exclusion of 25 165 to $30 \%$ of the total annual rainfall. This corresponds to the mean of predicted changes during 166 the dry season in the Mediterranean area at the end of the 21st century (i.e. 20-30\% decrease,

167 Giorgi 2006; Giorgi and Lionello 2008; Mariotti and others 2008; Dubrovsky and others 2014).

168 However, it would be more than the average change predicted for an entire year. For example,

169 by using CMIP3 multi-model simulations, Mariotti and others (2008) reported that climate 170 projections for the Mediterranean basin predict a 15\% decrease per year, with a higher decrease 171 during the dry season (-23\%) compared to the wet season (-10\%) when most of the total rainfall 172 occurs.

173 We quantified the exact amount of excluded rainfall in three ways: (i) with permanently 174 installed TDR100 probes (Campbell Scientific Inc., Logan, Utah) at $10 \mathrm{~cm}$ soil depth in seven 175 control and eight rain-excluded plots, respectively, (ii) using rain gauges at ground level 
underneath the gutters in both control and rain-excluded plots, and (iii) by determining the

177 gravimetric soil water content in soil samples from control and exclusion plots. These measurements indicated that we only occasionally reached the target value and that our exclusion system reduced the average annual precipitation by only $12 \pm 2 \%$ compared to the control plots. This seems to be mostly the consequence of wind turbulence during rainfall rendering the gutters covering the relatively small plot area of $16 \mathrm{~m}^{2}$ at a height of about $2 \mathrm{~m}$ above the ground not as effective as we anticipated. An average of $12 \%$ less rainfall, however, is close to the $15 \%$ mean annual decrease reported by the projections of 14 CMIP3 global climate models for the Mediterranean Basin (Mariotti and others 2008) and to the $10 \%$ mean annual decrease reported by the projections of 28 CMIP5 global climate models for southern France (Polade and others 2014). Moreover, we stress that a given percentage of excluded rainfall does not readily translate into a similarly reduced soil water content, which depends also on the total amount of precipitation during a single rainfall event and how these events are distributed. As a consequence, during certain rain events we measured between $-13 \%$ and $-24 \%$ lower soil volumetric water content at $10 \mathrm{~cm}$ soil depth in plots with partial rain exclusion compared to control plots (Supplementary Fig. S1).

Freshly fallen leaf litter of the four shrub species were collected over the whole period of maximum litterfall (June to July, 2011) using suspended litter traps. Every two days, leaf litter was retrieved from litter traps, air-dried at room temperature and stored until the beginning of the experiment. For the exposure of litter in the experimental plots we constructed "openbottom" PVC cylinders (5 $\mathrm{cm}$ tall) covered with $1 \mathrm{~mm}$ mesh net on top and with windows on the side covered with a $10 \mathrm{~mm}$ mesh. These cylinders allow direct contact of the litter with the soil surface and full access of the soil fauna without flattening the litter material as was suggested by Barantal and others (2011). Cylinders were filled with a total of six grams of airdried leaf litter reflecting the species composition of the respective plot, with equal proportions 
of the different litter species in the 11 multi-species litter mixtures. We installed seven cylinders

202 in the central $4 \mathrm{~m}^{2}$ part of each of the 92 plots, yielding a total of 644 cylinders. To place the cylinders we avoided rock outcrops and very shallow soil.

\section{Litter traits and decomposition}

Initial litter quality was determined from four subsamples of each species-specific litter batch (Supplementary Table S1). Carbon and N concentrations were determined by thermal combustion using a Flash EA 1112 series C/N elemental analyzer (Thermo Scientific, USA).

Phosphorus (P) concentrations were measured colorimetrically using the molybdenum blue method according to the protocol of Santonja and others (2015). Lignin concentration was determined according to the van Soest extraction protocol (van Soest and Wine 1967) using a

212 fiber analyzer (Fibersac 24; Ankom, Macedon, NJ, USA). The concentration of phenolics was measured colorimetrically using the method of Peñuelas and others (1996) with gallic acid as a standard. To determine the water holding capacity (WHC), intact leaf litter samples were soaked in distilled water for $24 \mathrm{~h}$, drained and weighed. The dry weight was determined after drying samples at $60{ }^{\circ} \mathrm{C}$ for $48 \mathrm{~h}$. WHC was calculated according to the formula: moist weight / dry weight $\times 100 \%$.

The community-weighted mean traits $(\mathrm{CWM})$ of litter mixtures were calculated as the average trait values of litter mixtures following Garnier and others (2004) as:

$$
\text { Trait }_{\mathrm{CWM}}=\sum_{i=1}^{n} p_{i} \times \text { trait }_{i}
$$

221 where $p_{i}$ is the relative abundance for species $i$ and trait $t_{i}$ is the trait value for species $i$. 222 Functional dissimilarity (FD) was calculated according to Rao's quadratic entropy (Botta Dukat 2005; Epps and others 2007) for each litter mixture as:

$$
\text { Trait }_{\mathrm{FD}}=\sum_{\mathrm{i}=1}^{\mathrm{n}} \sum_{\mathrm{j}=1}^{\mathrm{n}} p i p j * d i j
$$


where $p_{i}$ and $p_{j}$ are the relative abundance for shrub species $i$ and $j$ in the litter mixture, and $d_{i j}$ 226 the Euclidian distance between species $i$ and $j$ for the trait considered. Because the measured traits differ in their units, we used normalized values (using a z-scored standardization so as to get a mean of zero and a standard deviation of one) to calculate functional dissimilarity.

of field exposure. We considered the first year as an initial stage of decomposition that is 231 dominated by leaching losses, which can account for up to $30 \%$ of initial mass depending on 232 litter species (Berg and McClaugherty 2008). Mass loss in our study varied between 18.6\% 233 (Ulex) and 36.5\% (Cistus) in the single species treatments after one year. The advanced 234 decomposition during the second year, we defined here as a later stage of decomposition with 235 a range of mass loss between $27.0 \%$ (Ulex) and 53.0\% (Quercus) in the single species 236 treatments after two years. We retrieved four replicates in December 2012 (368 mesocosms) and three replicates in December 2013 (276 mesocosms) of plot-specific leaf litter. The remaining leaf litter was put in plastic bags, and immediately transferred to the laboratory. Leaf 239 litter was separated into species, thoroughly brushed to remove adhering soil particles, freeze240 dried (Lyovac GT2®) and weighed to obtain litter dry mass data of each species in each 241 mesocosm. After weighing the component litter species, all litter from an individual field 242 mesocosm was again put together and then ground using a ball mill to a fine powder before 243 chemical analyses. Carbon and $\mathrm{N}$ concentrations were measured from remaining litter material 244 using the same procedure as described for initial concentrations. Initial and final concentrations 245 of $\mathrm{C}$ and $\mathrm{N}$ after one year, and after two years of decomposition were multiplied with initial, 246 and final litter mass after one and two years, respectively, for the calculation of the amount of $247 \mathrm{C}$ and $\mathrm{N}$ loss. The difference between initial amounts and those remaining after one year was 248 used to calculate total $\mathrm{C}$ and $\mathrm{N}$ release during the first year of decomposition. The difference 
between the amounts remaining after one year and after two years was used to calculate total $\mathrm{C}$

250 and $\mathrm{N}$ release during the second year of decomposition.

\section{Statistical analyses}

Statistical analyses were performed with the R software (R Core Team 2016) with significance levels indicated as $*$ for $\mathrm{P}<0.05, * *$ for $\mathrm{P}<0.01$ and $* * *$ for $\mathrm{P}<0.001$. We used

255 a linear mixed-effects model approach ("nlme" package) to test the effect of diversity, partial rain exclusion, and decomposition (initial and later) stage and their interactions on $\mathrm{C}$ and $\mathrm{N}$ release. To take into account the fact that we had four and three replicate mesocosms per plot for first year and second year, respectively, the random part of the model indicated that the mesocosms were nested within plots with the following $\mathrm{R}$ syntax ("random = $260 \sim 1$ plot/mesocosm"). Due to the large number of potentially important predictors, we carried out three distinct statistical models to test for the litter diversity effect on $\mathrm{C}$ and $\mathrm{N}$ release. The first model tested the impact of litter species richness (i.e. the number of litter species decomposing together (1 to 4 species)), precipitation treatment, year of decomposition, and their interactions. As the "nlme" package does not permit inclusion of species richness and species composition simultaneously in the model because mixtures containing all four litter types also represent the same community composition, a second complementary model was used to test the impact of litter species composition (i.e. the specific combinations of litter species, corresponding to 15 litter treatments), precipitation treatment, year of decomposition, and their interactions. In a third model we tested the impact of litter species identity (i.e. the presence/ absence of a particular species), precipitation treatment, year of decomposition, and their interactions. To take into account the effects of soil heterogeneity between plots, we

272 included the scores of the first axis of PCA analyses of plot-specific soil characteristics as a 
274 details). These soil characteristics included texture, $\mathrm{pH}$, cation exchange capacity (CEC), and 275 the concentrations of carbon, nitrogen, calcium, magnesium, sodium, potassium, iron, 276 manganese and aluminum. The full models were then simplified to determine the most 277 parsimonious models using the stepAIC function of the "MASS" package, an established model 278 selection procedure with both forward and backward selection algorithms, which ranks all 279 candidate models (all possible combinations of the initial explanatory variables included in the 280 full model) based on lowest AICs. The $r^{2}$ of the models were determined by using the r.squaredGLMM function of the "MuMin" package, a function allowing to estimate the marginal and conditional $r^{2}$ for mixed effects models. We present the $r^{2}$ and AIC values for both the full model (with all initial explanatory variables) and the most parsimonious model.

For a more detailed understanding of how the diversity of leaf litter affected $\mathrm{C}$ and $\mathrm{N}$ release during litter decomposition, we evaluated the effects of mean traits (Trait ${ }_{\mathrm{CWM}}$ ) and functional trait dissimilarities (Trait $\mathrm{FD}$ ) of the 11 measured litter traits (Supplementary Table S1). Firstly, we conducted a principal component analysis (PCA) using the CWM or the FD values of the 11 measured litter traits. CWM1 and CWM2, and FD1 and FD2 represented the two first components of the PCAs conducted using the CWM or the FD values across litter mixtures. Secondly, we performed linear mixed-effects models (i.e. the same approach as for the litter diversity effect) in order to decipher the relative contributions of Trait ${ }_{\mathrm{CWM}}$ and Trait FD $_{\mathrm{F}}$ tested conjointly. In this last model we tested the effects of the Traits ${ }_{\text {CWM }}$ (i.e. CWM1 and CWM2), Traits $\mathrm{FD}$ (i.e. FD1 and FD2), precipitation treatment, year of decomposition, and their 294 interactions on $\mathrm{C}$ and $\mathrm{N}$ release.

RESULTS 
Both $\mathrm{C}$ and $\mathrm{N}$ release from decomposing litter differed strongly between the first and second year of decomposition, regardless whether the model fitted litter species richness (Table 1) or litter species composition (Table 2). The $\mathrm{C}$ release was higher during the first year compared to the second year of decomposition (Figs. 1 and 2). In contrast, there was overall more $\mathrm{N}$ released during the second year compared to the first year of decomposition (Figs. 1 and 2).

In the statistical models including the effect of species richness, we found that litter $\mathrm{C}$ and $\mathrm{N}$ release were significantly affected by the interaction between year of decomposition and species richness (Table 1). This interaction resulted because the proportion of $\mathrm{C}$ and $\mathrm{N}$ release increased with species richness during the first year but not during the second year of decomposition (Fig. 1a and 1b). After one year of decomposition, the average $\mathrm{C}$ release increased from $31 \%$ in monospecific litters to $35 \%$ in 4 -species mixtures, whereas the $\mathrm{N}$ release increased from $8 \%$ in monospecific litters to $17 \%$ in 4 -species mixtures. The amount of variation explained by species richness was comparatively small, especially for $\mathrm{C}$ release.

313 However, the positive relationship with species richness was robust, with similar or even higher 314 variation explained when the 4 -species level was excluded from the analysis $\left(R^{2}=0.14\right.$ and 3150.13 for $\mathrm{C}$ and $\mathrm{N}$ loss, respectively), or when the few microcosms showing apparent $\mathrm{N}$ immobilization (mostly at low species richness) were excluded from the analysis $\left(\mathrm{R}^{2}=0.17\right.$ for 317 N loss).

In the complementary statistical models testing the importance of species composition 319 (i.e. the 15 distinct litter treatments), we found that litter species composition strongly affected 320 C and N release (Table 2; Supplementary Table S2). As indicated by the significant litter composition $\times$ year interaction, the differences between the 15 litter treatments depended on 322 the year of decomposition (Table 2; Supplementary Table S2). Most of the litter treatments lost 323 roughly twice to three times less $\mathrm{C}$ during the second year compared to the first year of 
decomposition, but a few treatments lost much less (Ulex single species litter), or almost the

325 identical amount of C (Quercus alone or mixed with Cistus) during the second year compared

326 to the first year of decomposition. For $\mathrm{N}$ loss, the differences between one and two years of 327 decomposition varied even more (Supplementary Table S2). The differences between the litter 328 treatments increased during the second year compared to the first year of decomposition for C 329 release $(\mathrm{CV}=16 \%$ and $36 \%$ for one and two years of decomposition, respectively), but not for $330 \mathrm{~N}$ release $(\mathrm{CV}=53 \%$ and $45 \%$ for one and two years of decomposition, respectively) 331 (Supplementary Table S2).

332 As litter composition significantly affected the $\mathrm{C}$ and $\mathrm{N}$ release, we further assessed the 333 effects of the presence or absence of particular litter species (i.e. effects of litter species identity; 334 Table 3; Fig. 3). The statistical model incorporating species identity effects (Table 3) showed 335 that the presence of Quercus consistently led to higher C and $\mathrm{N}$ release (Fig. 3). The presence 336 of Quercus litter enhanced C release to a larger extent during the second year than during the 337 first year of decomposition ( $+51 \%$ and $+17 \%$, respectively) but enhanced $\mathrm{N}$ release to a larger 338 extent during the second year $(+240 \%)$ compared to the first year of decomposition $(+69 \%)$ 339 (Table 3; Fig. 3). The presence of Cistus increased the release of C (+13\%) but not that of N, 340 regardless of the year of decomposition (Fig. 3). The presence of Ulex generally decreased C 341 and $\mathrm{N}$ release, and these effects were more pronounced during the second year $(-37 \%$ and $-30 \%$ 342 for $\mathrm{C}$ and $\mathrm{N}$ release, respectively) compared to the first year of decomposition (-14\% and $-21 \%$ 343 for $\mathrm{C}$ and $\mathrm{N}$ release, respectively) (Table 3; Fig. 3). Finally, the presence of Rosmarinus had 344 the least consistent effects with a slight positive effect on $\mathrm{C}$ release during the first year of 345 decomposition (+6\%) that turned into a negative effect during the second year decomposition 346 (-13\%) (Table 3; Fig. 3). The neutral Rosmarinus effect on $\mathrm{N}$ release during the first year of 347 decomposition turned into a strongly negative effect during the second year of decomposition 348 (-33\%) (Table 3; Fig. 3). 


\section{Consequences of reduced precipitation on $C$ and $N$ release during decomposition}

The partial rain exclusion we applied to the experimental plots overall had weak effects

on $\mathrm{C}$ and $\mathrm{N}$ release during decomposition. In fact, partial rain exclusion did not have a

significant main effect in any of the statistical models we ran (Tables 1 to 4 ). The release of $\mathrm{C}$,

but not that of $\mathrm{N}$, however, was distinctly affected by reduced rainfall among the different litter treatments (small but significant litter composition $\times$ partial rain exclusion effect, Table 2).

With less rainfall, the monospecific Rosmarinus litter released less C (25\% vs. 37\%) whereas the monospecific Ulex litter released more C (23\% vs. 20\%). Overall, these differences were

small and most of the litter treatments did not show any difference between plots with partial rain exclusion and control plots (data not shown). Partial rain exclusion interacted with the year of decomposition to influence $\mathrm{N}$ release, but not that of $\mathrm{C}$ (Table 2; Figs. 2a and 2b). Indeed, across all litter treatments there was $17 \%$ less $\mathrm{N}$ release with reduced precipitation compared to control plots during the first year of decomposition, while $\mathrm{N}$ release was similar in both treatments during the second year of decomposition (Fig. 2b).

\section{CWM- versus FD-trait control over $C$ and $N$ release}

Principal component analysis (PCA) of CWM traits showed that the first PCA axis

367 (CWM1) explaining 61.7\% variation was determined by high scores of $\mathrm{P}$ concentration and WHC, but low values of $\mathrm{C}$ concentration, and low ratios of $\mathrm{C}: \mathrm{P}, \mathrm{N}: \mathrm{P}$ and lignin:P (Fig. 4a). High scores of the second PCA axis (CWM2) explaining 28.2\% variation were related to high

370 values of lignin concentration, and high ratios of $\mathrm{C}: \mathrm{N}$ and lignin: $\mathrm{N}$, while low scores were 371 associated with high concentrations of $\mathrm{N}$ and phenolics. When considering the functional trait 372 dissimilarity, the first PCA axis (FD1) explaining $43.3 \%$ variation separated litter mixtures 373 according to increasing dissimilarity of WHC values, the concentrations in $\mathrm{C}$ and $\mathrm{P}$, and $\mathrm{N}: \mathrm{P}$ 
and C:P ratios (Fig. 4b). High scores along the second axis (FD2) explaining 28.1\% variation were largely determined by $\mathrm{N}$-related traits with increasing dissimilarity in $\mathrm{N}$ concentration, and $\mathrm{C}: \mathrm{N}$ and lignin: $\mathrm{N}$ ratios, while low scores were related to increasing dissimilarity in the concentrations of lignin and phenolics (Fig. 4b).

When evaluating conjointly the effects of CWM and FD traits in linear mixed-effects models, we found that $\mathrm{C}$ release was mostly controlled by the CWM2 and the interactions CWM1 $\times$ year and FD2 $\times$ year (Table 4). Increasing CWM1 scores (i.e. increasing values of WHC and P concentration) and decreasing CWM2 scores (i.e. increasing values of $\mathrm{N}$ and phenols concentration) were related to higher $\mathrm{C}$ release during both years of decomposition (Fig. 5). The interaction between CWM1 and year of decomposition resulted from a stronger relationship between C release and CWM1 during the second year compared to the first year of decomposition (Table 4; Fig. 5). Functional dissimilarity in trait values had no main effect on $\mathrm{C}$ release, but there was a significant interaction between FD2 and year of decomposition (Table 4), showing that increasing functional dissimilarity in initial $\mathrm{N}$ concentrations and $\mathrm{C}: \mathrm{N}$, and Lignin: $\mathrm{N}$ ratios stimulated $\mathrm{C}$ release during the second year of decomposition (Figs. 4 and 5). The $\mathrm{N}$ release was significantly affected by CWM2, FD1 as well as the interactions CWM1 $\times$ year, FD2 $\times$ year and rainfall reduction $\times$ year $($ Table 4$)$. Similar to what we observed for $\mathrm{C}$ release, increasing CWM1 scores and decreasing CWM2 scores were related to higher $\mathrm{N}$ release (Fig. 5), with a stronger impact of CWM1 during the second year of decomposition (significant CWM1 $\times$ year interaction, Table 4; Fig. 5). In contrast to $\mathrm{C}$ release, functional trait dissimilarity showed strong main effects on $\mathrm{N}$ release (Table 4). The FD1 effect indicates that decreasing functional dissimilarity in WHC and the concentrations of $\mathrm{C}$ and $\mathrm{P}$, as well as the $\mathrm{P}$ stoichiometry led to higher $\mathrm{N}$ release (Figs. 4 and 5). On the other hand, increasing FD2 scores (i.e. increasing dissimilarity in $\mathrm{N}$ concentration, and $\mathrm{C}: \mathrm{N}$, and Lignin: $\mathrm{N}$ ratios) led to higher $\mathrm{N}$ 
release only during the second year of decomposition (Fig. 5) as indicated by the FD2 $\times$ year 399 interaction (Table 4).

\section{DISCUSSION}

402

\section{Litter $C$ and $N$ release in response to changing plant diversity}

Leaf litter decomposition we measured here for the four plant species is similar to that reported for a range of other Mediterranean woody plant species (Fioretto and others 2003; Gallardo and Merino 2003; Castro and others 2010; Almagro and Martinez-Mena 2012). In agreement with our first hypothesis, we observed higher $\mathrm{C}$ and $\mathrm{N}$ release with increasing litter species richness only during the first year of decomposition (0-12 months) and not during the second year of decomposition (12-24 months). These positive richness effects remained comparatively small and accounted with $8 \%$ for $\mathrm{C}$ release and $15 \%$ for $\mathrm{N}$ release, which was only a minor part of the observed variability. However, the positive relationship between $\mathrm{C}$ and $\mathrm{N}$ loss and species richness was not a spurious statistical results. This relationship remain robust when we ran the analysis without the 4-species level or by excluding the $\mathrm{N}$ immobilizing litter at lower species levels. Relatively low variation accounted for by species richness is a common result in plant diversity experiments where composition effects (variability within richness levels) typically dominate over richness effects (Hooper and Vitousek 1997; Wardle and others 1997; Tilman and others 2014). This was also the case in our study with the statistical models

418 based on species richness explaining respectively 2 and 5 times less variability in $\mathrm{C}$ and $\mathrm{N}$ 419 release than the models based on litter species composition (Tables 1 and 2). Accordingly, changes in species richness will have only a small additional impact on $\mathrm{C}$ and $\mathrm{N}$ cycling in the studied Mediterranean shrubland compared to shifts in species composition or other spatially and temporally varying factors. These include for example fire or UV-radiation that both were 
shown to critically control litter decomposition in drylands (e.g. Austin and Vivanco 2006;

424 Throop and others 2017), and which would have to be included for a more general assessment

of how biogeochemical cycling is changing in response to climate and biodiversity change at relevant spatial and temporal scales.

A stimulation of litter decomposition with increasing species richness can occur due to a greater diversity of substrates varying in physico-chemical properties when more species are present in mixtures (Hättenschwiler and others 2005; Kominoski and others 2007; Vos and others 2013). This could enhance the available niches for soil biota, and thus lead to higher decomposer abundance and activity (Hättenschwiler and others 2005). Higher fungal and bacterial abundance with increasing litter species richness was indeed reported in the same litter samples we analyzed here after one year of exposure in the field (Santonja and others 2017a). Litter species richness effects are expected to occur mainly during the early stages of decomposition when litter characteristics differ the most among litter species. In contrast, richness effects may decrease in the later stages of decomposition as litter quality and chemical diversity converge (Melillo and others 1989; Chomel and others 2014; Parsons and others 2014; but see Wickings and others 2012). However, the effects of litter composition persisted over time and became even stronger during the second year compared to the first year of decomposition for C release. These results rather support the "Initial Litter Quality Hypothesis" stating that initial litter trait effects persist during later stages of decomposition (Berg and McClaugherty 2008) and is in line with the recent findings of Wickings and others (2012) who reported that the chemistry of different litter types diverge during the decomposition process. This may also explain why the composition is generally more important than the richness of litter mixtures in the majority of litter diversity experiments (e.g. Kominoski and others 2007; Vivanco and Austin 2008; Santonja and others 2015, and this study). Rather than the number of species, the specific litter traits represented by the different species composing the mixture 
448 are driving the diversity effects. Indeed, we identified strong species identity effects on 449 decomposition in our study. In general, Cistus and Quercus positively affected C and N release, 450 whereas Ulex had negative effects. Differences in litter traits among these three species may 451 explain their opposite effects. Quercus and Cistus had lower lignin and higher P concentrations 452 compared to Ulex, two litter traits known to control litter decomposition. Quercus and Cistus 453 also had a higher WHC than Ulex, a physical trait affecting litter humidity, which is important 454 for decomposer activity (Hättenschwiler and others 2005; Makkonen and others 2013; Santonja 455 and others 2015). However, the intensity of the effects of Quercus and Ulex varied depending 456 on the year of decomposition. Moreover, Rosmarinus had a positive effect during the first year, 457 while its effect became negative during the second year of decomposition. Collectively, these 458 changing species identity effects over time highlight the fact that litter identity effects are not 459 necessarily constant during the decomposition process. Plant diversity can also affect decomposition independently from litter quality by modifying soil characteristics or microclimatic conditions (e.g. Joly et al. 2017). With a detailed assessment of soil parameters in each of the 92 experimental plots, we statistically accounted

463 for an important part of environmental heterogeneity among plots and potential long-term 464 effects of plant community composition beyond the quality of litter fall. These soil 465 characteristics indeed had some rather minor effects on $\mathrm{C}$ release, but not on $\mathrm{N}$ release, in addition to our main treatment factors. However, by exposing the different litter treatments underneath the canopy of the same plant species composition, our data represent well the overall 468 changes in $\mathrm{C}$ and $\mathrm{N}$ loss dynamics during decomposition in response to a shift in plant diversity, 469 irrespective of the relative contribution of direct litter trait and indirect plant canopy effects.

\section{Litter $C$ and $N$ release in response to reduced precipitation}



significant reduction in decomposition with reduced water availability (e.g. Saura-Mas and others 2012; Almagro and others 2015; Santonja and others 2015; Santonja and others 2017b).

Based on these studies, we predicted that partial rain exclusion would slow down the $\mathrm{C}$ and $\mathrm{N}$ release from the litter, and more so during the second year compared to the first year of 477 decomposition, as Garcia-Palacios and others (2016) showed an increase in the relative 478 importance of abiotic controls in later compared to earlier decomposition stages. In contrast to 479 these previous studies and our second hypothesis, reduced precipitation did not have large 480 effects on $\mathrm{C}$ release. The extent of negative effects of reduced rainfall may depend on the type 481 of ecosystem, but also on the amount of rainfall that is removed. The small effects we observed 482 are likely due to the comparatively small change in precipitation with an average of $12 \%$ less 483 annual rainfall, which is lower than in most partial rain exclusion experiments, but close to the 484 average predictions for the Mediterranean Basin (-15\%, Mariotti and others 2008) and for southern France (-10\%, Polade and others 2014). In addition, Mediterranean decomposer communities are rather drought tolerant and might be less affected by slight changes in the 487 amount of rainfall compared to other ecosystem types. In fact, the strong seasonal shifts in both 488 temperature and soil water availability and the rather extreme environmental conditions during 489 summer typical for the Mediterranean climate could represent a strong selection pressure for 490 microbial decomposer communities, resulting in high drought tolerance (Curiel-Yuste and 491 others 2014). Moreover, decomposition might be under stronger direct control of solar UV492 radiation, which can have a strong impact on surface litter decomposition in drylands (Austin 493 and Vivanco 2006; Almagro and others 2015; Almagro and others 2017), overriding the indirect 494 effects of the small difference in precipitation we simulated here. The $\mathrm{N}$ release was more sensitive to our precipitation treatment compared to $\mathrm{C}$ release, 496 probably because the release of $\mathrm{N}$ differs in its dynamics compared to that of $\mathrm{C}$ (Moore and 
others 2005; Garcia-Palacios and others 2016; Santonja and others 2017a). The relative

498 contribution of $\mathrm{N}$ immobilization $v s$. $\mathrm{N}$ release during litter decomposition depends on environmental conditions and initial litter quality (Parton and others 2007). Contrary to what we hypothesized, the $17 \%$ lower $\mathrm{N}$ release with less precipitation occurred during the first year rather than the second year of decomposition. This contrasts the earlier findings by Garcia502 Palacios and others (2016), who reported an increase in abiotic control (predominantly soil 503 moisture) over $\mathrm{C}$ and $\mathrm{N}$ release with proceeding decomposition. The different results may be related to an overall shorter time span of decomposition in Garcia-Palacios and others' (2016) study covering only the early stage decomposition according to the definition used in our study, different experimental setups (mass loss classes vs. specific time span) and different ecosystem types (forests vs. shrubland) that may respond distinctly to changes in abiotic conditions.

\section{CWM- versus FD-trait control over $C$ and $N$ release}

The functional trait-based metrics CWM (community weighted mean) and FD

511 (functional dissimilarity) allow to distinguish between mass-ratio and niche differentiation as 512 two key mechanisms of diversity effects. Actually, the models incorporating CWM and FD 513 explained more variation than the models based on species richness alone and a similar amount 514 of variation as the models based on species composition and species identity (Tables 1 to 3 ). 515 The metrics CWM and FD both predicted C and N loss, with FD being more important overall 516 for $\mathrm{N}$ release compared to $\mathrm{C}$ release. Carbon release was most strongly related to the first 517 component of the CWM-trait PCA, indicating that increasing total litter P concentration and 518 water holding capacity (WHC) stimulate C release. Accordingly, when the two relatively P519 rich litter species Cistus and Quercus, which also had comparatively high WHC, were present 520 in litter mixtures, $\mathrm{C}$ release was higher compared to when they were absent. Along with N, P is 521 a frequently limiting nutrient in Mediterranean ecosystems (McMaster and others 1982; Henkin 
and others 1998; Sardans and Peñuelas 2013), but P appears more important than N in driving

523 C release during litter decomposition in the studied shrubland. Maintaining litter humidity for

524 a longer time-period by high WHC may be particularly important for decomposer activity in

525 Mediterranean ecosystems (Hättenschwiler and others 2005; Makkonen and others 2013;

526 Santonja and others 2015). N release was determined more by the second component of the

527 CWM-trait PCA, identifying N concentration, N-based stoichiometric ratios, and phenolics as

528 the main drivers of $\mathrm{N}$ dynamics. It has previously been shown that the relative contribution of

$529 \mathrm{~N}$ immobilization $v s$. $\mathrm{N}$ release is strongly determined by the initial litter $\mathrm{N}$ concentration (Aber

530 and Melillo 1982; Parton and others 2007). In strong contrast to C release, both axes of the FD-

531 trait PCA were associated to $\mathrm{N}$ release patterns. In line with the niche complementarity

532 hypothesis, litter mixtures with contrasting litter quality may improve the availability of

533 different resources for decomposers (Schimel and Hättenschwiler 2007; Handa and others

534 2014). Similar to our results, Garcia-Palacios and others (2017) also identified litter CWM traits

535 to be important drivers of both, litter $\mathrm{C}$ and $\mathrm{N}$ release, and FD traits as additional major drivers

536 of litter $\mathrm{N}$ release. Collectively, these findings suggest that different aspects of litter trait

537 diversity control $\mathrm{C}$ and $\mathrm{N}$ dynamics during litter decomposition.

538 An important result reported here was that the first PCA axis of CWM-traits (i.e.

539 increasing total litter P concentration and WHC) and the second PCA axis of FD-traits (i.e.

540 increasing dissimilarity in N-related traits) accounted for more of the variance in the later than

541 the initial stage of decomposition for both $\mathrm{C}$ and $\mathrm{N}$ release. This pattern indicates that initial

542 litter traits maintain their importance in controlling elemental cycling in later stages of

543 decomposition, and that legacy effects of initial litter traits actually increase during the course

544 of litter decomposition (Garcia-Palacios and others 2016). Interestingly, legacy effects of litter

545 traits were not only expressed via mean traits of litter mixtures, but also by their dissimilarity

546 in N-related traits among litter species present in the mixture. In other words, $\mathrm{C}$ and $\mathrm{N}$ release 
547 in later stage decomposition increased in litter mixtures with increasing differences in initial $\mathrm{N}$

548 concentrations among component species rather than with overall high litter $\mathrm{N}$ content. It has

549 previously been suggested that fungi- or leaching-driven $\mathrm{N}$ transfer among litter species varying

550 in their initial $\mathrm{N}$ concentration may contribute to litter mixture effects (Schimel and

551 Hättenschwiler 2007; Vos and others 2013; Barantal and others 2014; Handa and others 2014).

552 In our study, however, this response may also result at least in part from species identity effects.

553 Indeed, the presence of the N-rich species Ulex in litter mixtures (i.e. mixtures with rather high

554 overall $\mathrm{N}$ content) had a negative effect on $\mathrm{C}$ and $\mathrm{N}$ release. This Ulex presence effect may also

555 originate from low WHC and low $\mathrm{P}$ concentration, the two traits driving the CWM trait 556 response.

557

\section{CONCLUSION}

559 Changes in the diversity of dominant shrub species in the studied Mediterranean

560 shrubland had stronger effects on $\mathrm{C}$ and $\mathrm{N}$ release during litter decomposition than a moderate

561 reduction in precipitation. Litter species richness had a small positive effect on $\mathrm{C}$ and $\mathrm{N}$ release

562 only during the first year of decomposition. The litter diversity effects were mostly driven by

563 the presence of particular litter species and their litter traits. Surprisingly, these effects were

564 stronger during the second than the first year of decomposition, suggesting increasing legacy

565 effects of initial litter traits with ongoing decomposition. Furthermore, our analyses of litter

566 functional trait-based metrics support the view that both mass-ratio and niche complementarity

567 are important in understanding plant diversity control over elemental cycling in decomposing

568 plant litter. 
5727263 (Marseille) for their contribution to the set-up of the experiment and the field work. We 573 specially thank Sylvie Dupouyet for her tireless assistance during the field work, Caroline 574 Lecareux and Germain Boungou for their assistance to the chemical analyses, and Jean-Philippe 575 Mévy for the acquisition of meteorological and soil humidity data. Funding was provided by 576 the Agence Nationale de la Recherche (ANR) through the project CLIMED (ANR-09-CEP577 007). We also thank the French Region PACA and Europe for the PhD grant attributed to 578 Mathieu Santonja. Finally, the authors declare no conflict of interest.

\section{AUTHOR'S CONTRIBUTIONS}

M.S., V.B., A.R., and S.H. designed the study; M.S. and A.R. conducted the experiment 582 and collected the data; M.S., A.M. and S.H. analyzed the data and led the writing of the manuscript. All authors contributed critically to the drafts and gave final approval for 584 publication.

586 REFERENCES

587 Aber JD, Melillo JM. 1982. Nitrogen immobilization in decaying hardwood leaf litter as a 588 function of initial nitrogen and lignin content. Canadian Journal of Botany 60:2263-2269. 589 Almagro M, Martínez-Mena M. 2012. Exploring short-term leaf-litter decomposition dynamics 590 in a Mediterranean ecosystem: dependence on litter type and site conditions. Plant and Soil $591 \quad 358: 323-335$.

592 Almagro M, Maestre FT, Martínez-López J, Valencia E, Rey A. 2015. Climate change may 593 reduce litter decomposition while enhancing the contribution of photodegradation in dry 594 perennial Mediterranean grasslands. Soil Biology and Biochemistry 90:214-223. 
Almagro M, Martinez-Lopez J, Maestre FT, Rey A. 2017. The contribution of photodegradation to litter decomposition in semiarid Mediterranean grasslands depends on its interaction with local humidity conditions, litter quality and position. Ecosystems 20:527-542.

Austin AT, Vivanco L. 2006. Plant litter decomposition in a semi-arid ecosystem controlled by photodegradation. Nature 442:555-558.

600 Barantal S, Roy J, Fromin N, Schimann H, Hättenschwiler S. 2011. Long-term presence of tree 601 species but not chemical diversity affect litter mixture effects on decomposition in a 602 neotropical rainforest. Oecologia 167:241-252.

603 Barantal S, Schimann H, Fromin N, Hättenschwiler S. 2014. C, N and P fertilization in an 604 Amazonian rainforest supports stoichiometric dissimilarity as a driver of litter diversity 605 effects on decomposition. Proceedings of the Royal Society B 281:20141682.

606 Bellard C, Bertelsmeier C, Leadley P, Thuiller W, Courchamp F. 2012. Impacts of climate 607 change on the future of biodiversity. Ecology letters 15:365-377.

608 Berg B, Berg MP, Bottner P, Box E, Breymeyer A, Anta RCD, ... Santo AVD. 1993. Litter 609 mass loss rates in pine forests of Europe and Eastern United States: some relationships with 610 climate and litter quality. Biogeochemistry 20:127-159.

611 Berg B, Mcclaugherty C. 2008. Plant litter: Decomposition, humus formation and carbon 612 sequestration. Springer, Berlin.

613 Botta Dukát Z. 2005. Rao's quadratic entropy as a measure of functional diversity based on 614 multiple traits. Journal of Vegetation Science 16:533-540.

615 Bradford MA, Berg B, Maynard DS, Wieder WR, Wood SA. 2016. Understanding the 616 dominant controls on litter decomposition. Journal of Ecology 104:229-238.

617 Castro H, Fortunel C, Freitas H. 2010. Effects of land abandonment on plant litter 618 decomposition in a Montado system: relation to litter chemistry and community functional 619 parameters. Plant and Soil 333:181-190. 
Chomel M, Fernandez C, Bousquet-Mélou A, Gers C, Monnier Y, Santonja M, Gauquelin T,

621 Gros R, Lecareux C, Baldy V. 2014. Secondary metabolites of Pinus halepensis alter decomposer organisms and litter decomposition during afforestation of abandoned agricultural zones. Journal of Ecology 102:411-424.

624 Cornwell WK, Cornelissen JHC, Amatangelo K, Dorrepaal E, Eviner VT, Godoy O, ... 625 Westoby M. 2008. Plant species traits are the predominant control on litter decomposition 626 rates within biomes worldwide. Ecology Letters 11:1065-1071.

627 Coûteaux MM, Bottner P, Berg B. 1995. Litter decomposition, climate and litter quality. Trends 628 in Ecology and Evolution 10:63-66.

629 Cowling RM, Rundel PW, Lamont BB, Arroyo MK, Arianoutsou M. 1996. Plant diversity in 630 Mediterranean-climate regions. Trends in Ecology and Evolution 11:362-366.

631 Curiel-Yuste J, Peñuelas J, Estiarte M, Garcia-Mas J, Mattana S, Ogaya R, Pujol M, Sardans J. 632 2014. Drought-resistant fungi control soil organic matter decomposition and its response to 633 temperature. Global Change Biology 17:1475-1486.

634 Diaz S, Lavorel S, De Bello F, Quetier F, Grigulis K, Robson TM. 2007. Incorporating plant 635 functional diversity effects in ecosystem service assessments. Proceedings of the National 636 Academy of Sciences of the USA 104:20684-20689.

637 Dubrovsky M, Hayes M, Duce P, Trnka M, Svoboda M, Zara P. 2014. Multi-GCM projections 638 of future drought and climate variability indicators for the Mediterranean region. Regional 639 Environmental Change 14:1907-1919.

640 Epps KY, Comerford NB, Reeves III JB, Cropper Jr WP, Araujo QR. 2007. Chemical diversity641 highlighting a species richness and ecosystem function disconnect. Oikos 116:1831-1840.

642 Fioretto A, Papa S, Fuggi A. 2003. Litter-fall and litter decomposition in a low Mediterranean 643 shrubland. Biology and Fertility of Soils 39:37-44. 
644 Gallardo A, Merino J. 1993. Leaf decomposition in two Mediterranean ecosystems of southwest 645 Spain: influence of substrate quality. Ecology 74:152-161.

646 Garcia-Palacios P, Shaw EA, Wall DH, Hättenschwiler S. 2016. Temporal dynamics of biotic 647 and abiotic drivers of litter decomposition. Ecology Letters 19:554-563.

648 Garcia-Palacios P, Shaw EA, Wall DH, Hättenschwiler S. 2017. Contrasting mass-ratio vs. 649 niche complementarity effects on litter $\mathrm{C}$ and $\mathrm{N}$ loss during decomposition along a regional $650 \quad$ climatic gradient. Journal of Ecology 105:968-978.

651 Garnier E, Cortez J, Billès G, Navas ML, Roumet C, Debussche M, ... Toussaint JP. 2004. 652 Plant functional markers capture ecosystem properties during secondary $653 \quad$ succession. Ecology 85:2630-2637.

654 Giorgi F. 2006. Climate change hot-spots. Geophysical Research Letters 33: L08707.

655 Giorgi F, Lionello P. 2008. Climate change projections for the Mediterranean region. Global 656 and Planetary Change 63:90-104.

657 Grime JP. 1998. Benefits of plant diversity to ecosystems: immediate, filter and founder effects. 658 Journal of Ecology 86:902-910.

659 Handa IT, Aerts R, Berendse F, Berg MP, Bruder A, Butenschoen O, ... Hättenschwiler S. 660 2014. Consequences of biodiversity loss for litter decomposition across 661 biomes. Nature 509:218-221.

662 Hättenschwiler S, Tiunov AV, Scheu S. 2005. Biodiversity and litter decomposition in 663 terrestrial ecosystems. Annual Review of Ecology, Evolution and Systematics 36:191-218. 664 Henkin Z, Seligman NG, Kafkafi U, Noy-Meir I. 1998. Effective growing days: a simple 665 predictive model of response of herbaceous plant growth in a Mediterranean ecosystem to 666 variation in rainfall and phosphorus availability. Journal of Ecology 86:137-148.

667 Hooper DU, Vitousek PM. 1997. The effects of plant composition and diversity on ecosystem $668 \quad$ processes. Science 277:1302-1305. 
Joly FX, Milcu A, Scherer-Lorenzen M, Jean LK, Bussotti F, Dawud SM, ... Hättenschwiler S. 2017. Tree species diversity affects decomposition through modified microenvironmental conditions across European forests. New Phytologist 214:1281-1293.

Kominoski JS, Pringle CM, Ball BA, Bradford MA, Coleman DC, Hall DB, Hunter MD. 2007. Non-additive effects of leaf litter species diversity on breakdown dynamics in a detritusbased stream. Ecology 88:1167-1176.

Laughlin DC. 2011. Nitrification is linked to dominant leaf traits rather than functional diversity. Journal of Ecology 99:1091-1099.

Makkonen M, Berg MP, van Logtestijn RSP, van Hal JR, Aerts R. 2013. Do physical plant litter traits explain non-additivity in litter mixtures? A test of the improved microenvironmental conditions theory. Oikos 122:987-997.

Mariotti A, Zeng N, Yoon JH, Artale V, Navarra A, Alpert P, Li LZ. 2008. Mediterranean water cycle changes: transition to drier 21 st century conditions in observations and CMIP3 simulations. Environmental Research Letters 3:044001.

McMaster GS, Jow WM, \& Kummerow J. 1982. Response of Adenostoma fasciculatun and Ceanothus gregii chaparral to nutrient additions. Journal of Ecology 70:745-756.

Médail F, Quézel P. 1999. Biodiversity hotspots in the Mediterranean Basin: setting global conservation priorities. Conservation Biology 13:1510-1513.

Melillo JM, Aber JD, Linkins AE, Ricca A, Fry B, Nadelhoffer KJ. 1989. Carbon and nitrogen dynamics along the decay continuum: plant litter to soil organic matter. Plant and Soil 115:189-198.

Mokany K, Ash J, Roxburgh S. 2008. Functional identity is more important than diversity in influencing ecosystem processes in a temperate native grassland. Journal of Ecology 96:884893. 
Montès N, Maestre FT, Ballini C, Baldy V, Gauquelin T, Planquette M, ... Perret JB. 2008. On the relative importance of the effects of selection and complementarity as drivers of diversity productivity relationships in Mediterranean shrublands. Oikos 117:1345-1350.

Moore TR, Trofymow AJ, Siltanen M, Prescott C, CIDET Working Group. 2005. Litter decomposition and $\mathrm{C}, \mathrm{N}$ and $\mathrm{P}$ dynamics in upland forest and peatland sites, central Canada. Canadian Journal of Forest Research 35:133-142.

Myers N, Mittermeier RA, Mittermeier CG, Da Fonseca GA, Kent J. 2000. Biodiversity hotspots for conservation priorities. Nature 403:853-858.

Parsons SA, Congdon RA, Lawler IR. 2014. Determinants of the pathways of litter chemical decomposition in a tropical region. New Phytologist 203:873-882.

Parton W, Silver WL, Burke IC, Grassens L, Harmon ME, Currie WS, ... Fasth B. 2007. Global-scale similarities in nitrogen release patterns during long-term decomposition. Science 315:361-364.

Pearce-Higgins JW, Ockendon N, Baker DJ, Carr J, White EC, Almond RE, ... Butchart SH. 2015. Geographical variation in species' population responses to changes in temperature and precipitation. Proceedings of the Royal Society of London B 282:20151561

Peñuelas J, Estiarte M, Kimball BA, Idso SB, Pinter PJ, Wall GW, Garcia RL, Hansaker DJ, LaMorte RL, Hendrix DL. 1996. Variety of responses of plant phenolic concentration to CO2 enrichment. Journal of Experimental Botany 47:1463-1467.

Petchey OL, Gaston KJ. 2006. Functional diversity: back to basics and looking forward. Ecology Letters 9:741-758.

Polade SD, Pierce DW, Cayan DR, Gershunov A, Dettinger MD. 2014. The key role of dry days in changing regional climate and precipitation regimes. Scientific Reports 4:4364.

Preston CM, Nault JR, Trofymow A, Smyth C, CIDET Working Group. 2009. Chemical changes during 6 years of decomposition of 11 litters in some Canadian forest sites. Part 1. 

1077.

Quested H, Eriksson O, Fortunel C, Garnier E. 2007. Plant traits relate to whole-community litter quality and decomposition following land use change. Functional Ecology 21:10161026.

R Core Team. 2016. R: A language and environment for statistical computing. R Foundation for Statistical Computing, Vienna, Austria. URL https://www.R-project.org/.

Rodriguez-Ramirez N, Santonja M, Baldy V, Ballini C, Montès N. 2017. Shrub species richness decreases negative impacts of drought in a Mediterranean ecosystem. Journal of Vegetation Science 28 :985-996.

Santonja M, Fernandez C, Gauquelin T, Baldy V. 2015. Climate change effects on litter decomposition: intensive drought leads to a strong decrease of litter mixture interactions. Plant and Soil 393:69-82. P. 2017a. Plant litter diversity increases microbial diversity and carbon and nitrogen cycling in a Mediterranean shrubland. Soil Biology and Biochemistry 111:124-134.

Santonja M, Fernandez C, Gers C, Proffit M, Gauquelin T, Reiter I, Cramer W, Baldy V. 2017b. Plant litter mixture partly mitigates the negative effects of extended drought on soil biota and litter decomposition in a Mediterranean oak forest. Journal of Ecology 105:801-815.

Sardans J, Peñuelas J. 2013. Plant-soil interactions in Mediterranean forest and shrublands: impacts of climatic change. Plant and Soil 365:1-33.

739 Saura-Mas S, Estiarte M, Peñuelas J, Lloret F. 2012. Effects of climate change on leaf litter 740 decomposition across post-fire plant regenerative groups. Environmental and Experimental Botany 77:274-282. 
742 Schimel JP, Hättenschwiler S. 2007. Nitrogen transfer between decomposing leaves of different $743 \quad$ N status. Soil Biology and Biochemistry 39:1428-1436.

744 Shihan A, Hättenschwiler S, Milcu A, Joly FX, Santonja M, Fromin N. 2017. Changes in soil 745 microbial substrate utilization in response to altered litter diversity and precipitation in a 746 Mediterranean shrubland. Biology and Fertility of Soils 53:171-185.

747 Swift MJ, Heal OW, Anderson JM. 1979. Decomposition in terrestrial ecosystems. Berkeley: $748 \quad$ University of California press.

749 Thompson JD. 2005. Plant evolution in the Mediterranean. Oxford: Oxford University Press.

750 Throop HL, Abu Salem M, Whitford WG. 2017. Fire enhances litter decomposition and reduces 751 vegetation cover influences on decomposition in a dry woodland. Plant Ecology 218:799752811.

753 Tilman D, Isbell F, Cowles JM. 2014. Biodiversity and ecosystem functioning. Annual Review 754 of Ecology, Evolution, and Systematics 45:471-493.

755 Van Soest PU, Wine RH. 1967. Use of detergents in the analysis of fibrous feeds. IV. 756 Determination of plant cell-wall constituents. Journal of the Association of Official $757 \quad$ Analytical Chemistry 50:50-55.

758 Vivanco L, Austin AT. 2008. Tree species identity alters forest litter decomposition through 759 long-term plant and soil interactions in Patagonia, Argentina. Journal of Ecology 96:727$760 \quad 736$.

761 Vogel A, Eisenhauer N, Weigelt A, Scherer-Lorenzen M. 2013. Plant diversity does not buffer 762 drought effects on early-stage litter mass loss rates and microbial properties. Global Change 763 Biology 19:2795-2803.

764 Vos VCA, van Ruijven J, Berg MP, Peeters ETHM, Berendse F. 2013. Leaf litter quality drives 765 litter mixing effects through complementary resource use among detritivores. Oecologia $766 \quad 173: 269-280$. 
767 Wardle DA, Bonner KI, Nicholson KS. 1997. Biodiversity and plant litter: Experimental 768 evidence which does not support the view that enhanced species richness improves 769 ecosystem function. Oikos 79:247-258.

770 Wickings K, Grandy AS, Reed SC, Cleveland CC. 2012. The origin of litter chemical $771 \quad$ complexity during decomposition. Ecology Letters 15:1180-1188. 
775 Table 1. Effects of litter species richness, change in precipitation, and year of decomposition 776 on carbon and nitrogen release. Only the variables retained in the most parsimonious models 777 are reported (d.f. $=$ degrees of freedom, $P$-values $=* P<0.05$, *** for $P<0.001$ ). At the bottom 778 of the table the values of $\mathrm{R}^{2}$ and AIC weight of the general model including all factors (All) 779 and of the most parsimonious model (MPM) are shown. Soil characteristics and precipitation 780 treatment were initially included in the models based on litter species richness, but they were 781 not retained in the most parsimonious models.

782

\begin{tabular}{|c|c|c|c|c|c|}
\hline & \multirow[b]{2}{*}{ d.f. } & \multicolumn{2}{|c|}{ Carbon release } & \multicolumn{2}{|c|}{ Nitrogen release } \\
\hline & & $F$-value & $P$-value & $F$-value & $P$-value \\
\hline (Intercept) & 1 & 1837.8 & $* * *$ & 459.9 & $* * *$ \\
\hline Richness (R) & 1 & 1.7 & & 4.6 & $*$ \\
\hline Year (Y) & 1 & 213.4 & $* * *$ & 21.9 & $* * *$ \\
\hline $\mathrm{R} \times \mathrm{Y}$ & 1 & 5.4 & $*$ & 17.2 & $* * *$ \\
\hline All $R^{2}(\mathrm{AIC})$ & \multicolumn{3}{|c|}{$0.31(4234.2)$} & \multicolumn{2}{|c|}{$0.12(4390.8)$} \\
\hline MPM R $^{2}$ (AIC) & \multicolumn{3}{|c|}{$0.30(4226.7)$} & \multicolumn{2}{|c|}{$0.11(4383.9)$} \\
\hline
\end{tabular}

783

784 
785 Table 2. Effects of litter species composition, change in precipitation and year of 786 decomposition on carbon and nitrogen release. Only the variables retained in the most 787 parsimonious models are reported (d.f. $=$ degrees of freedom, $P$-values $=* P<0.05, * * P<$ 7880.01 , and $* * * P<0.001)$. The term "soil characteristics" refers to plot-specific soil parameters 789 that were systematically included in all models as co-variable. At the bottom of the table the 790 values of $\mathrm{R}^{2}$ and AIC weight of the general model including all factors (All) and of the most 791 parsimonious model (MPM) are shown.

792

\begin{tabular}{|c|c|c|c|c|c|}
\hline & \multirow[b]{2}{*}{ d.f. } & \multicolumn{2}{|c|}{ Carbon release } & \multicolumn{2}{|c|}{ Nitrogen release } \\
\hline & & $F$-value & $P$-value & $F$-value & $P$-value \\
\hline (Intercept) & 1 & 12089.2 & $* * *$ & 2143.6 & $* * *$ \\
\hline Soil characteristics & 1 & 8.1 & $* *$ & & \\
\hline Composition (C) & 14 & 33.6 & $* * *$ & 27.1 & $* * *$ \\
\hline Precipitation $(\mathrm{P})$ & 1 & 0.5 & & 3.0 & \\
\hline Year $(\mathrm{Y})$ & 1 & 435.9 & $* * *$ & 55.7 & $* * *$ \\
\hline $\mathrm{C} \times \mathrm{P}$ & 14 & 2.1 & $*$ & & \\
\hline $\mathrm{C} \times \mathrm{Y}$ & 14 & 7.0 & $* * *$ & 13.7 & $* * *$ \\
\hline $\mathrm{P} \times \mathrm{Y}$ & 1 & & & 5.3 & $*$ \\
\hline All $R^{2}$ (AIC) & \multicolumn{3}{|c|}{$0.68(4078.6)$} & \multicolumn{2}{|c|}{$0.56(4223.7)$} \\
\hline MPM R ${ }^{2}$ (AIC) & \multicolumn{3}{|c|}{$0.67(4065.1)$} & \multicolumn{2}{|c|}{$0.54(4191.1)$} \\
\hline
\end{tabular}


795 Table 3. Effects of the presence of litter species, change in precipitation, and year of 796 decomposition on carbon and nitrogen release. Only the variables retained in the most 797 parsimonious models are reported (d.f. $=$ degrees of freedom, $P$-values $=* P<0.05, * * P<$ $7980.01, * * *$ for $P<0.001)$. The term "soil characteristics" refers to plot-specific soil parameters 799 that were systematically included in all models as co-variable. At the bottom of the table the 800 values of $\mathrm{R}^{2}$ and AIC weight of the general model including all factors (All) and of the most 801 parsimonious model (MPM) are shown.

802

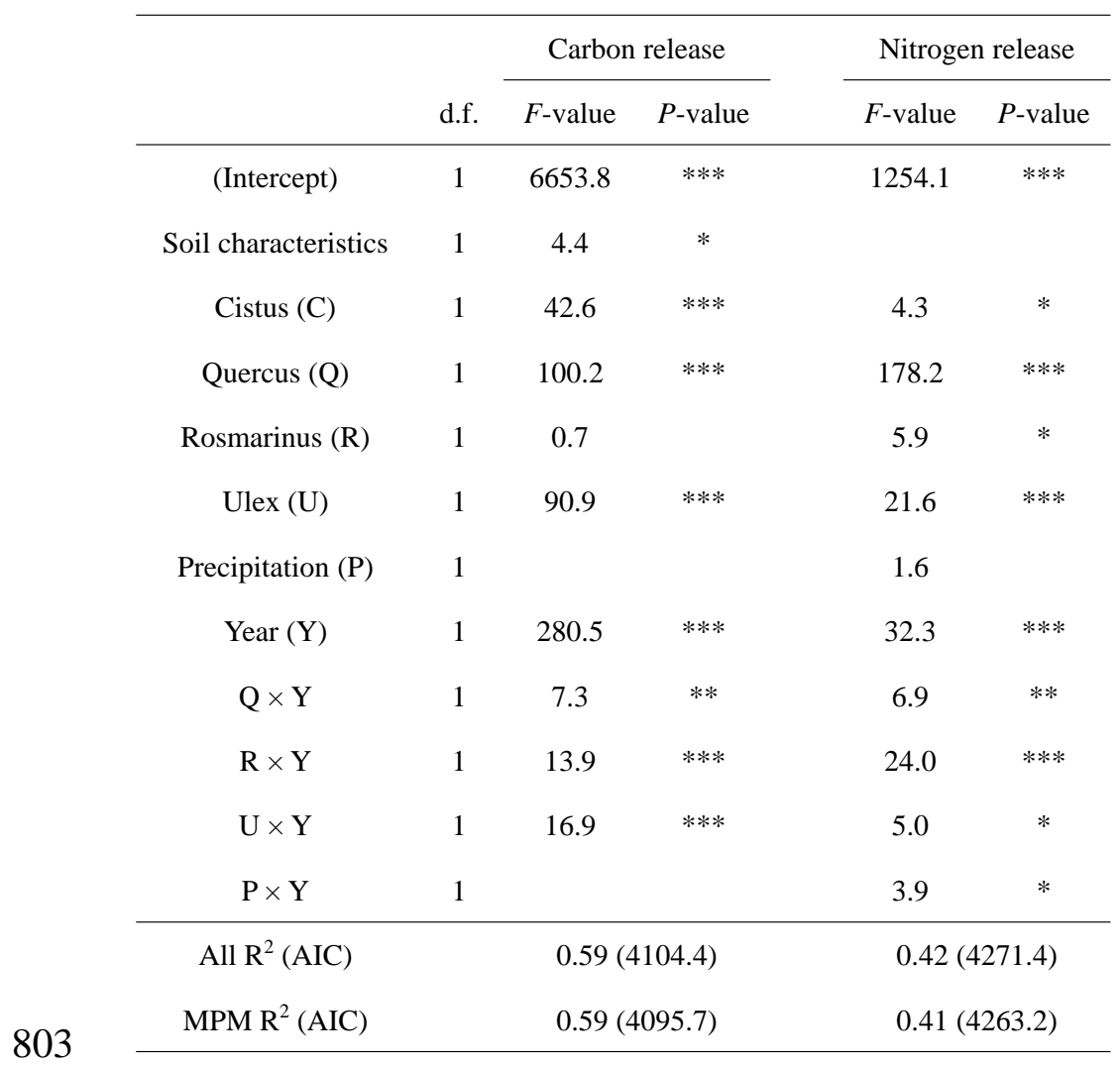

804 
805 Table 4. Effects of community weighted mean traits (CWM), functional trait dissimilarity (FD), 806 change in precipitation, and year of decomposition on carbon and nitrogen release. CWM1 and 807 CWM2, and FD1 and FD2 represented the two first components of the PCAs conducted using 808 the CWM or the FD values in Fig. 4. Only the variables retained in the most parsimonious 809 models are reported (d.f. $=$ degrees of freedom, $P$-values $=* P<0.05$, ** $P<0.01$, *** for $P$ $810<0.001)$. At the bottom of the table the values of $\mathrm{R}^{2}$ and AIC weight of the general model 811 including all factors (All) and of the most parsimonious model (MPM) are shown.

812

\begin{tabular}{|c|c|c|c|c|c|}
\hline & \multirow[b]{2}{*}{ d.f. } & \multicolumn{2}{|c|}{ Carbon release } & \multicolumn{2}{|c|}{ Nitrogen release } \\
\hline & & $F$-value & $P$-value & $F$-value & $P$-value \\
\hline (Intercept) & 1 & 10596.3 & $* * *$ & 1474.7 & $* * *$ \\
\hline CWM1 & 1 & 145.3 & $* * *$ & 6.4 & $*$ \\
\hline CWM2 & 1 & 98.9 & $* * *$ & 135.3 & $* * *$ \\
\hline FD1 & 1 & & & 54.9 & $* * *$ \\
\hline FD2 & 1 & 0.0 & & 18.8 & $* * *$ \\
\hline Precipitation $(\mathrm{P})$ & 1 & 0.0 & & 2.8 & \\
\hline Year (Y) & 1 & 430.4 & $* * *$ & 26.0 & $* * *$ \\
\hline $\mathrm{CWM} 1 \times \mathrm{Y}$ & 1 & 9.1 & $* *$ & 29.1 & $* * *$ \\
\hline $\mathrm{FD} 2 \times \mathrm{Y}$ & 1 & 29.3 & $* * *$ & 47.9 & $* * *$ \\
\hline $\mathrm{P} \times \mathrm{S}$ & 1 & 2.8 & & 4.2 & $*$ \\
\hline All R² (AIC) & \multicolumn{3}{|c|}{0.62 (2981.7) } & \multicolumn{2}{|c|}{$0.43(3165.8)$} \\
\hline $\mathrm{MPM} \mathrm{R}^{2}$ (AIC) & \multicolumn{3}{|c|}{$0.62(2970.2)$} & \multicolumn{2}{|c|}{$0.43(3159.8)$} \\
\hline
\end{tabular}


817 Fig. 1. Carbon (a) and nitrogen (b) release as a function of litter species richness during the first 818 year $(\mathrm{Y} 1=$ white symbol) and the second year of decomposition (Y2 = grey symbol). Each 819 symbol represents the mean value $(n=4$ microcosms per plot for $Y 1$, and $n=3$ microcosms for 820 Y2) of each of the 92 experimental plots. The $\mathrm{C}$ and $\mathrm{N}$ release values are indicated in percent 821 loss relative to the initial amount (for the first year of decomposition) or relative to the amount 822 remaining after 12 months of decomposition (for the second year of decomposition). Significant 823 linear relationships after one year of decomposition are indicated with dotted lines, adjusted $R^{2}$ 824 and associated $P$-values $* * P<0.01, * * * P<0.001)$.
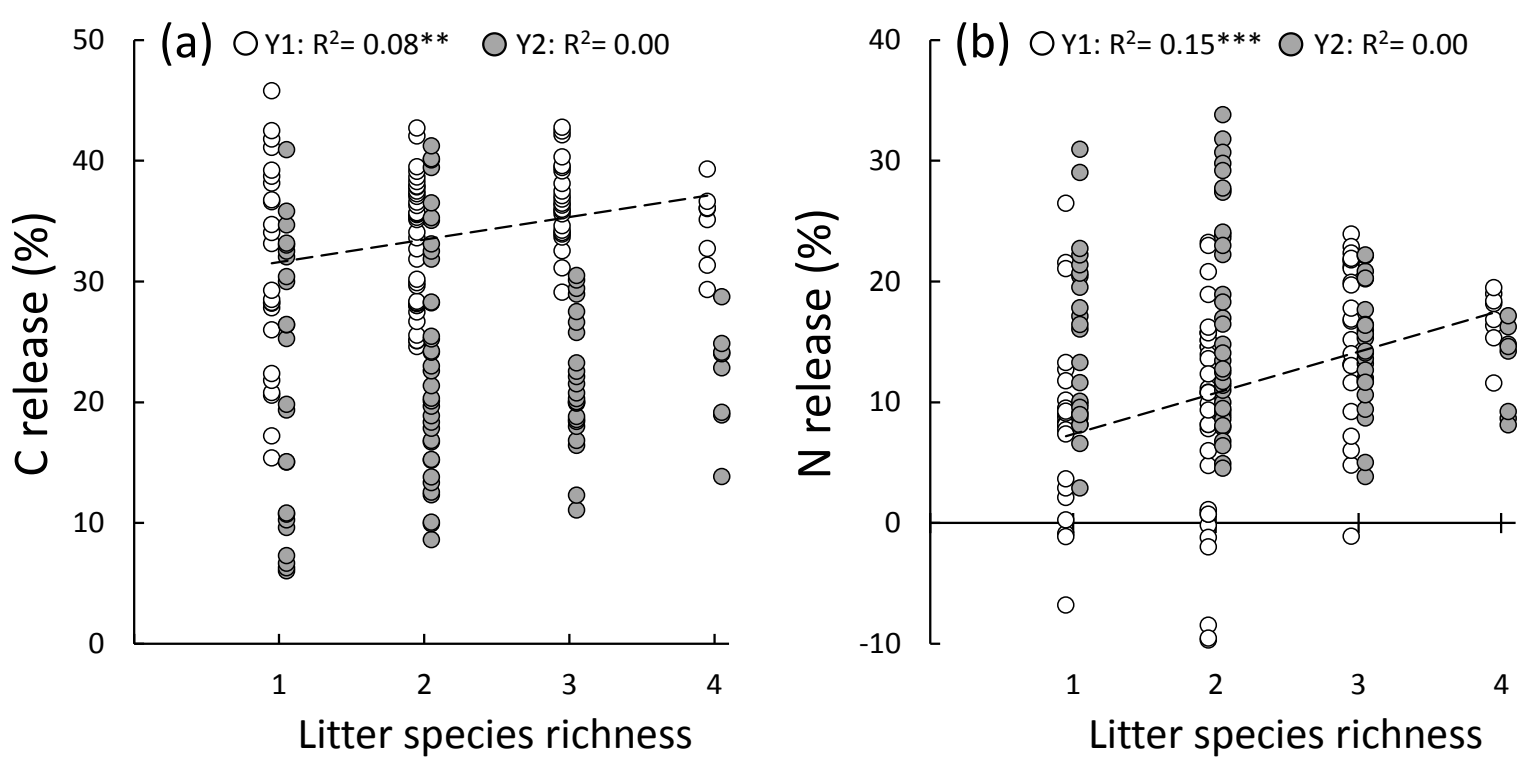
828 Fig. 2. Carbon (a) and nitrogen (b) release in control plots (white bars) and plots with partial 829 rain exclusion (black bars) during the first year (Y1 $=0$ to 12 months) and the second year of 830 decomposition ( $\mathrm{Y} 2=12$ to 24 months). Each bar represents the mean value \pm SE per 831 precipitation treatment; $\mathrm{n}=184$ and 138 microcosms for the first and the second year of

832 decomposition, respectively. The $\mathrm{C}$ and $\mathrm{N}$ release values are indicated in percent loss relative 833 to the initial amount (for the first year of decomposition) or relative to the amount remaining 834 after 12 months of decomposition (for the second year of decomposition). Stars denote 835 significant differences between control plots and plots with partial rain exclusion $(* P<0.05)$. 836
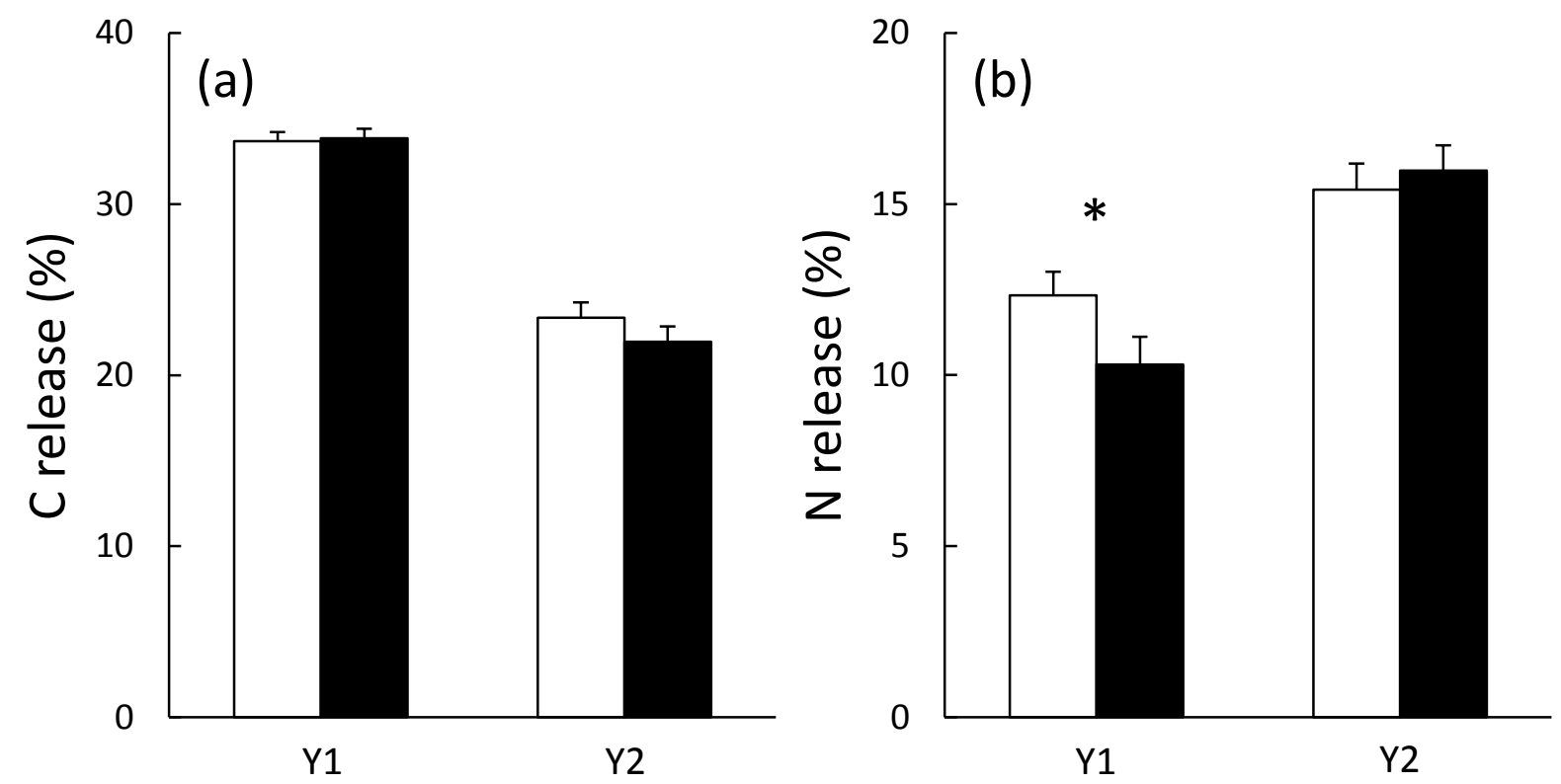

837 
839 Fig. 3. Carbon (panels a and b) and nitrogen (panels $\mathrm{c}$ and d) release in the presence of a

840 particular litter species $($ presence $=$ white bar and absence $=$ striped bar) during the first year

841 (panels a and c) and the second year of decomposition (panels b and d). Each bar represents the

842 mean value \pm SE. In (a) and (c), n = 200 and 168 microcosms for species presence and absence,

843 respectively. In (b) and (d), $n=150$ and 126 microcosms for species presence and absence,

844 respectively. The values are indicated in percent loss relative to the initial amount (for the first

845 year of decomposition) or relative to the amount remaining after 12 months of decomposition

846 (for the second year of decomposition). Stars denote significant differences between mixtures

847 containing the specific species and in its absence ( $* P<0.05$, ** $P<0.01$, *** $P<0.001)$.

848
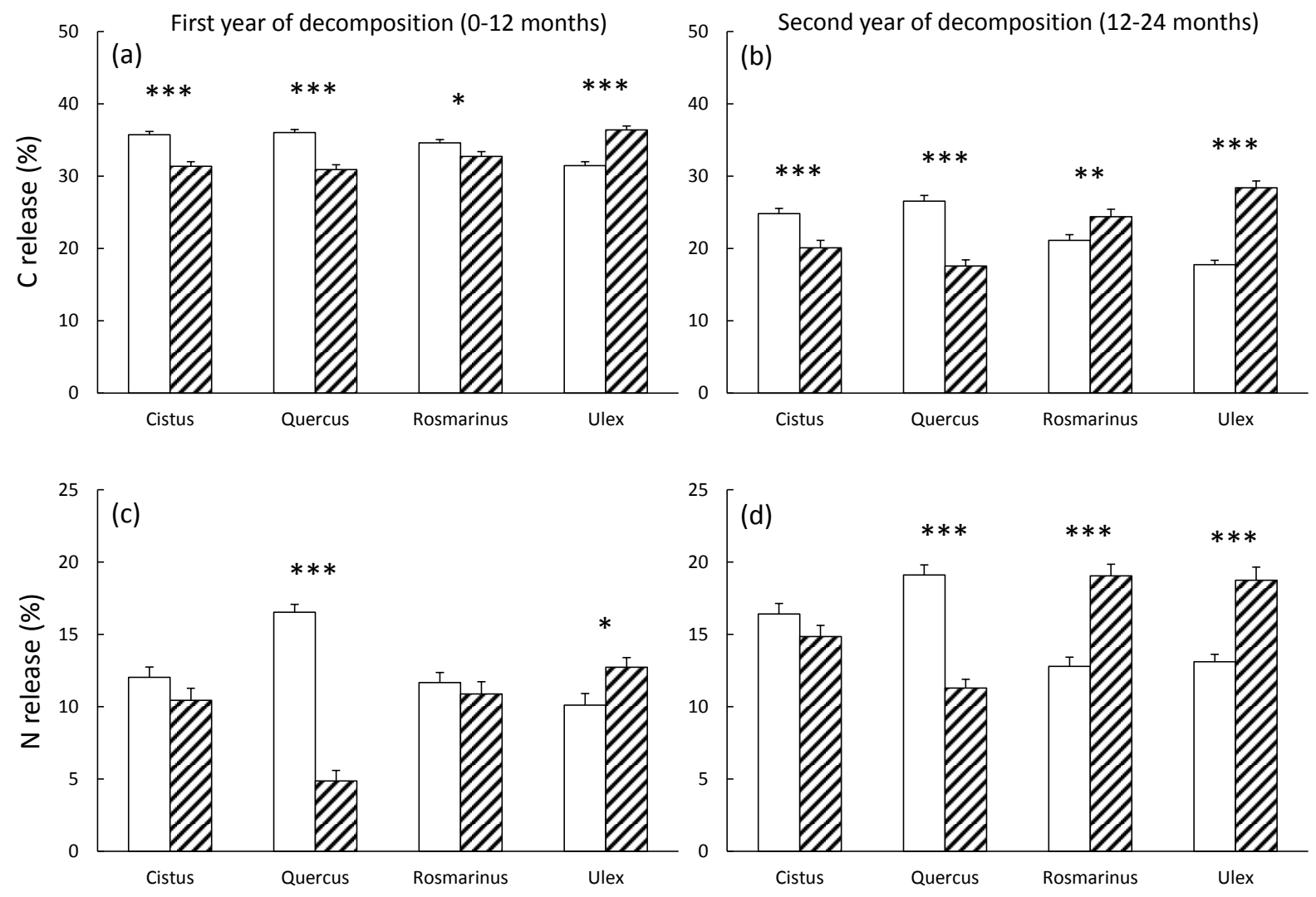
851 Fig. 4. Principal component analysis (PCA) of community-weighted mean traits (a) and

852 functional trait dissimilarity (b). Variance explained by each principal component and 853 associated eigenvalues are shown in brackets. CWM = Community-Weighted Mean Trait, FD

$854=$ Functional Trait Dissimilarity. $\mathrm{C}=$ Cistus, $\mathrm{Q}=$ Quercus, $\mathrm{R}=$ Rosmarinus, $\mathrm{U}=\mathrm{Ulex}$.

855 Combinations of capital letters correspond to combinations of plant species in litter mixtures.

856

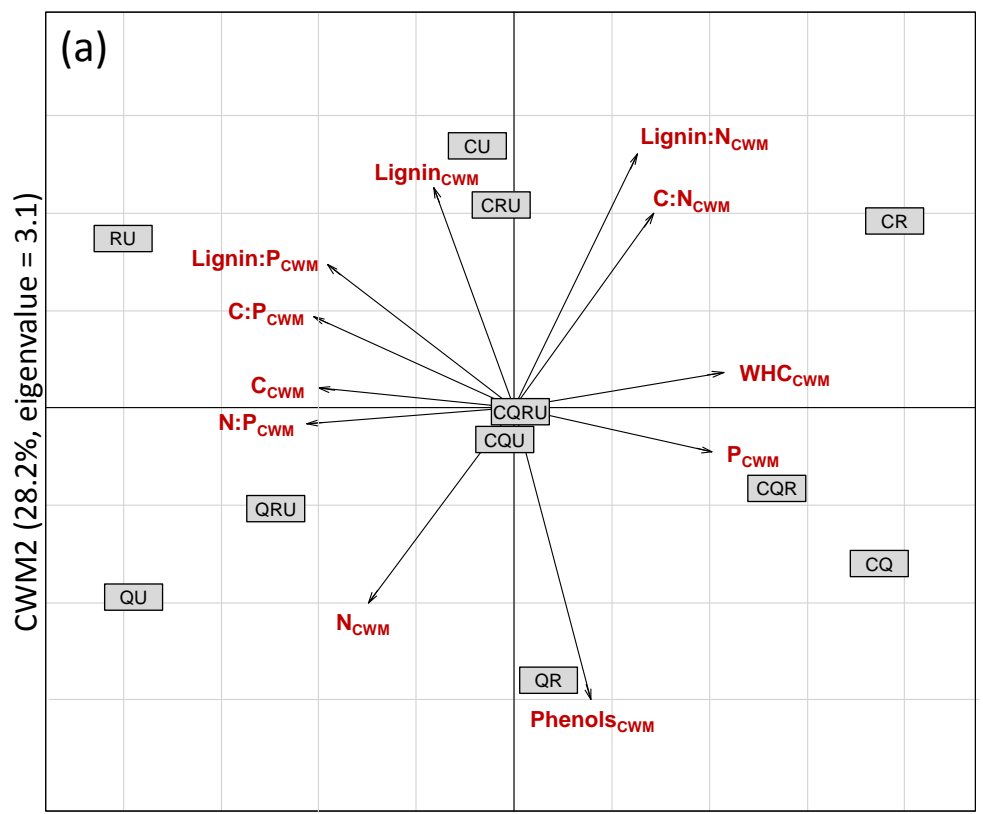

CWM1 $(61.7 \%$, eigenvalue $=6.8)$

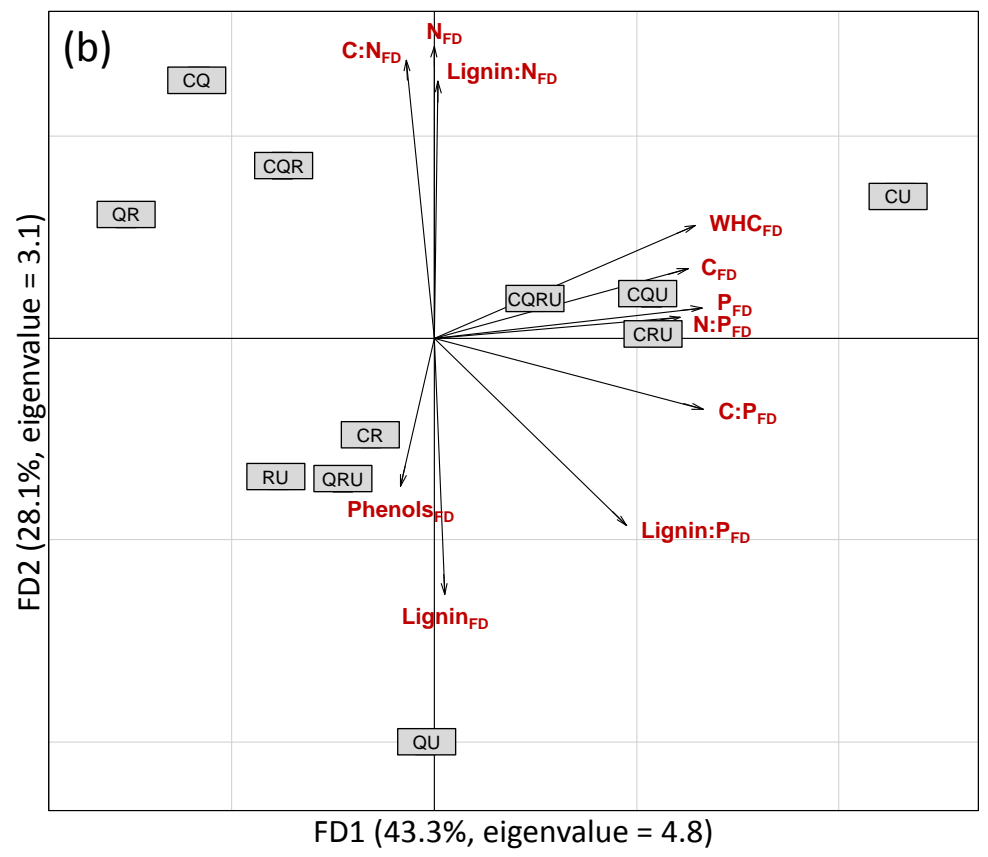


859 Fig. 5. Carbon (panels a, b, c and d) and nitrogen (panels e, f, g and h) release as a function of 860 community weighted mean traits (CWM1 and CWM2; panels a, b, e and f) and functional trait 861 dissimilarities (FD1 and FD2; panels c, d, g and h) during the first year (Y1 = white symbol) 862 and the second year of decomposition (Y2 = grey symbol). Each symbol represents the mean 863 value ( $\mathrm{n}=4$ and 3 microcosms per plot for Y1 and Y2, respectively) of each of the 68 multi864 species experimental plots. Significant relationships retained in the linear mixed-effects model 865 (Table 4) are indicated with dotted (Y1) or grey lines (Y2), adjusted $R^{2}$ and associated $P$-values 866 $(* P<0.05, * * P<0.01, * * * P<0.001)$.

867
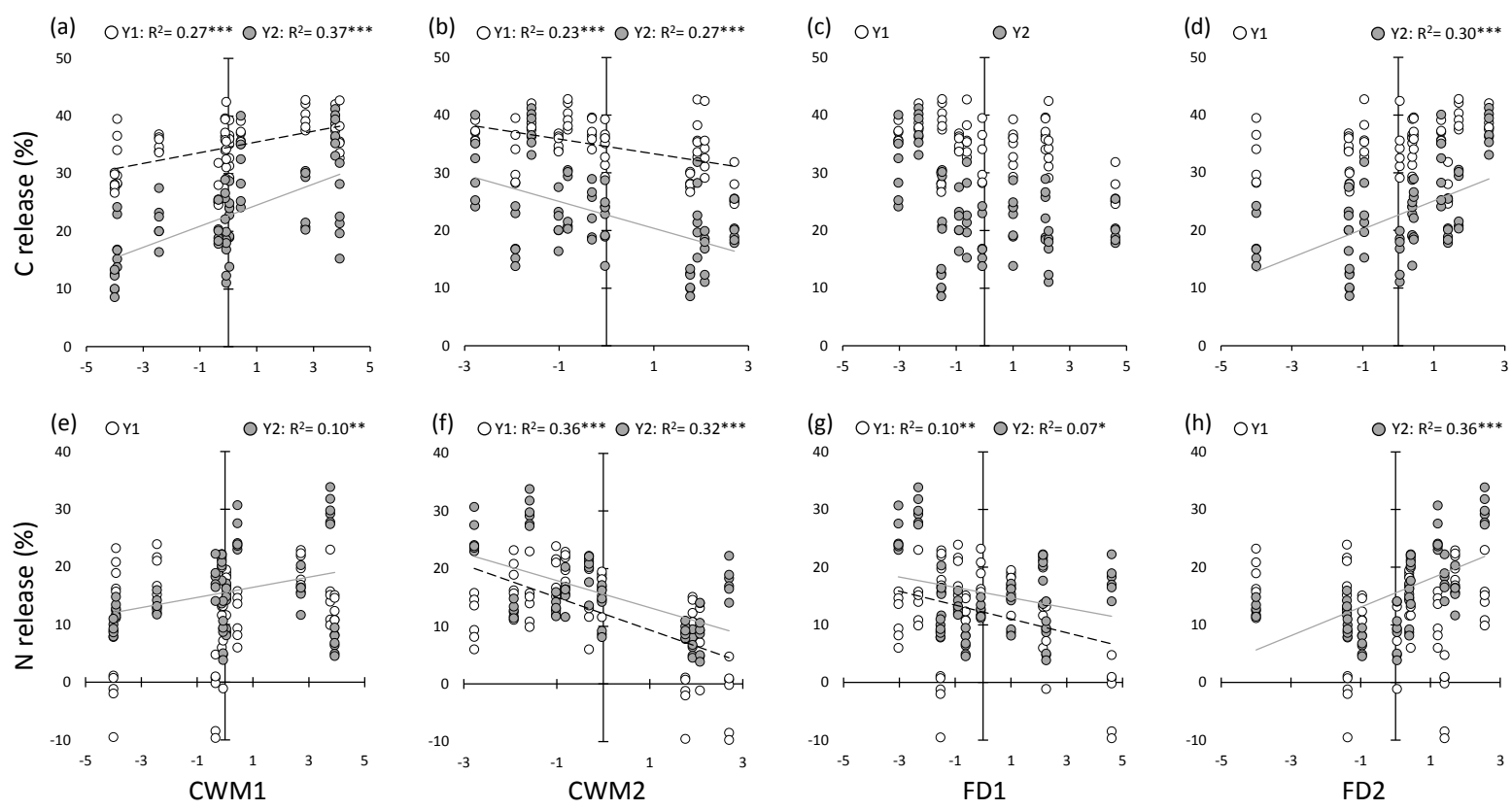